\title{
災害による道路通行規制時の交通選択行動に関する実証分析* \\ Empirical Studies on Travel Choice Behaviour \\ in a Road Network Degraded by Natural Disasters
}

朝倉康夫**, 柏谷增男 ${ }^{* * *}$, 高木一浩****, 藤原健一郎 ${ }^{* * * * *}$

by Yasuo Asakura and Masuo Kashiwadani,Kazuhiro Takagi and Ken-Ichiro Fujiwara

\section{1.はじめに}

道路ネットワークシステムの信頼性に関する研究の 蓄積は，ここ数年の間にかなり充実してきている(1). しかし，多くの研究では，ネットワーク上を流れる交 通フローの記述を捨象するかあるいはきわめて単純に 記述し，交通網を単純ネットワーク（pure network）と して扱ってきた(2)(3). リンクの通行可能確率を求める 時点で配分シミュレーションなどにより交通フローを 考慮している場合もあるが(4)，連結度の計算過程では pure networkとして考えていることに変わりはない.し たがって,リンクが通行不能になった際のトリップ メーカーの経路変更に伴う交通流の変化や, 結果とし て生じる可能性のある代替経路の機能低下などは十分 に考慮されてこなかった.

最近，ネットワークの一部が物理的に機能しないと きの交通流の変化を明示的に考慮した信頼性に関する 理論研究(5)(6)や実証研究も始められている(7)(8)。これ らは、流れのネットワーク (flow network) における信 頼性分析ということができる. モデル構築において は, 信頼性指標の効率的計算法の研究が重要である が，それと同時に，通行不能区間を持つネットワーク 上の交通流を記述するサブモデルを開発することが重 要である.

通行規制時の交通量配分の手法としては，これまで にリンク容量制約付きの需要変動型確率配分モデル(8) や，Burrell のモデルを応用した確率配分モデル(9)が提

*)Keywords ; 交通行動分析,経路選択,防災計画，交通量配分

${ }^{* *}$ )正会員工博愛媛大学助教授工学部檈境建設工学科 (下790松山市文京町,TEL.089-927-9829,FAX.089-927-9843)

${ }^{* * *}$ ) フエロー工博愛媛大学教授工学部環境建設工学科 ****)学生員 愛媛大学大学院 博士前期課程士木海洋工学専攻 $\left.{ }^{* * * * *}\right)$ 正会員 セントラルコンサルタント(株) 広島支店
案されてきた. しかしながら, いずれの場合でも道路 網の一部が利用できない状態におけるドライバーの交 通行動の記述には，大胆な仮説を設けざるを得なかっ たし，また，実際の経路選択行動の検証が十分であつ たとはいえない.

そこで，本研究の目的は，災害によって通行規制さ れたネットワークにおけるドライバーの交通選択行動 について実証的な分析を行うことにある. 具体的に は, 以下の $2 つ の$ 視点から四国地域の一般ドライバー を対象にアンケート調查を実施した結果を分析する.

(1)過去に災害による通行規制に遭遇した経験の有無と その際の交通選択行動

(2)仮想的な通行規制条件下での交通選択行動

そして, 得られた行動モデルを四国地域の道路ネット ワークに適用し, 交通量配分モデル構築のための基礎 的検討を行うものである.

この研究は, 災害時の道路網信頼性評価モデルに組 み込むことのできる交通量配分モデル開発のための基 礎的分析として位置づけられる. 以下，2では災害時 の道路網信頼性評価モデルの考え方と配分モデルの役 割，3 では交通行動調查の概要，4では実際の通行規 制時の行動に関する集計分析の結果，5では仮想的状 況下での選択行動モデルの推定，6では 5 で得られた モデルを四国地域道路網へ適用した結果について述べ る.

\section{2. 災害時の道路網信頼性訐価モテルの考え方}

(1)信頼性評価モデルの全体構造 (7)

ネットワークの連結状態を状態ベクトル $\mathbf{x}$, 状態の 発生確率を $\mathrm{p}(\mathbf{x})$ で表す. $\mathrm{x}$ の要素は $(0,1)$ でリンクが通行 可能であれば1，不通であれば0である．それぞれの に対してODペアrs間が機能していると判断されるとき 
1, 機能していないと判断されるとき0を取る関数であ る稼働・停止関数 $\mathrm{Z}_{\mathrm{rs}}(\mathbf{x})$ を求め, その数学的期待値を ODペアrs間の信頼度とする.

\section{(2) 配分モデルの役割}

ODペア間の連結度によって信頼性を評価するなら， すなわち，ネットワークの状態がxであるときに，OD ペア間が物理的に連結しているか否かにより稼働・停 止関数を評価するのであれば，配分計算は必要ではな い.しかしながら，物理的な連結度のみによる信頼性 指標は，「交通ネットワーク」の評価指標としては必 ずしも十分ではない，たとえば，残された通行可能り ンクに集中した交通による混雑は，ネットワークのパ フォーマンスを著しく低下させ，実質的に通行できな いのとほとんど変わらない状態を生じさせるかもしれ ない.

ネットワーク交通流から求められるOD間の旅行時間 や交通需要水準などを介在させて稼働・停止関数を評 価するのであれば，何らかの方法による配分計算が必 要になる. 災害時ネットワークを対象とした配分が平 常時の配分と異なる点は, 部分的に通行できないネッ トワークにおけるドライバーの迁回行動や，平常時に 比較して迁回距離（もしくは時間）が余りに長いこと によるトリップ中止行動を記述しなければならない点 にある．ドライバーの交通選択行動としてとらえるな ら，たとえば，トリップを中止するか否かの選択が第 1 段階, トリップを中止しない場合の迁回経路の選択 が第 2 段階の選択であるような構造を想定することも できる．いずれにしても，一部の区間が通行できない 状態のネットワークにおけるドライバーの交通選択行 動を記述できる配分モデルが必要であるということに なる。

\section{3. 交通行動調查の掼要}

災害時の道路ネットワーク利用に関する交通行動分 析のためのパイロットデータを得るために, 1995年11 月にアンケート調查を実施した. アンケートは, 通行 規制の経験とその際の行動を被験者が記入する調査票 I と, 仮想状況下での交通選択行動を記入する調查票 IIから構成されている. 調査対象者は一般ドライバー
であるが，建設省四国地方建設局の各工事事務所及び 愛媛県久万土木事務所を通じて配布できる者に限定し た. 配布数計 200 に対し 180 人から回答を得た.

調查票 I では主に以下の内容を尋ねた.

(1)過去に自然災害による通行止めに遭遇した経験があ るか否か。

(2)規制に遭遇したときトリップを中止したかどうか.

(3)規制に遭遇したとき, 迁回したか, 復旧後平常ルー トを利用したか.

(4)迁回ルートを利用した場合の道路名と所要時間.

調査票Iでは, 被験者に選択対象となる仮想のネッ トワーク（図.1）と経路の所要時間の組み合わせをい くつか与えてその選好を尋ねた. 平常ルートを利用し たとき, 过回ルートを利用したとき, 復旧するまで待 機して平常ルートを利用したときの 3 つの場合の所要 時間をそれぞれ与えて, 次の 3 つの選択肢から 1 つを 選択するものである.

1. 平常ルートが復旧するまで待つ，（待機）

2. 迁回ルートを利用する.（迁回）

3. 目的地へ行くことを取りやめる.（中止）

なお，交通目的による選択の差異を想定して，目的を 通勤・業務・観光・私用の 4 目的に分け， 1 被験者に 対して各目的ごとにそれぞれ 3 回（計12回）の選択回 答を求めた.

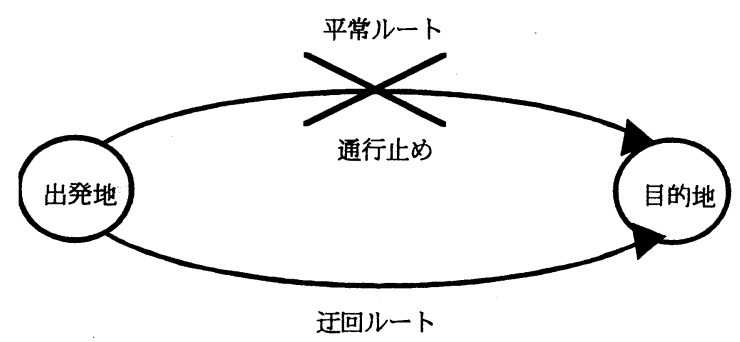

図.1調查票 II で用いた仮想ネットワーク

それぞれの選択肢の所要時間は, 次のようにして設 定した. 平常ルートの所要時間の值は, 四国地域にお ける道路交通センサスの結果などを参考にして, 交通 目的別に上下限值を設定し，その範囲でランダムに与 えた. 各目的別の所要時間の範囲は, 通勤（30 90 分）, 業務（30１80分）, 観光（60１80分），私用

(30〜120分）である. 迁回ルートの所要時間も同様に ランダムに与えた. その下限值は平常ルートの所要時 
間と一致させ, 上限値は交通目的別に, 通勤 (630 分）, 業務 (1080分)，観光 (900分)，私用 $(600$ 分）とした. 待機した場合の所要時間も下限値と上限 値の間でランダムに与えた. 下限值は平常ルートの所 要時間+100分，上限值は，交通目的別に，通勤（900 分）, 業務 (1800分), 観光 (1800分)，私用（1200 分）とした. すなわち，規制時間の長さを最小100分, 最大約15〜30時間と設定したことに相当する. 四国地 域において過去に発生した事前通行規制の時間延長 は，概ね数時間〜24時間の範囲にある. 上記の設定 は，それとほぼ対応したものとなっている.

\section{4. 実際の通行規制の行動（調查票Iの分析）}

(1)通行規制時のトリップ中止・待機行動

過去に通行規制に遭遇した被験者数は77名で, 全体 の 4 割を越える. 表.1は通行規制の経験のある被験者 （77名）のうち，規制時にトリップを中止した人数と 割合を交通目的別に示したものである. 目的計では11 名が通行規制時にトリップを中止しており，77名に対 する割合は約 $15 \%$ である，目的別に見ると，通勤・業 務目的では通行規制時でも $90 \%$ 以上の人がトリップを しており,トリップを中止する割合は低い。一方, 観 光目的では約 $30 \%$, 私用目的の場合には50\%以上が卜 リップを取りやめている.

通行規制時にもトリップを中止しなかった65名（目 的不明を除く）について迁回・待機の別に集計する と, 迂回路を利用した者が59名（91\%），待機が4名（ 6\%)，回答なしが2名（3\%）であった，一旦待機した 後にトリップする割合は低いといえる.

表.1 交通目的別トリップ中止数と中止率

\begin{tabular}{|c|c|c|c|c|c|c|c|}
\hline & 通勤 & 業駇 & 钼光 & 私用 & その他 & 目的不明 & 䛨 \\
\hline サンプル数 & 30 & 17 & 7 & 9 & 13 & 1 & $\pi$ \\
\hline 中止数 & 3 & 1 & 2 & 5 & 0 & - & 11 \\
\hline 中止率 (\%) & 10 & 5.9 & 28.5 & 55.6 & 0 & - & 14.3 \\
\hline
\end{tabular}

\section{(2)経路変更の実態}

通行規制に遭遇して迁回路を利用したドライバー59 名のうち, 利用ルートの変更に回答のあった55名につ いて変更パターンをまとめたのが表.2である. 最も多 いのが二析国道から三析国道への変更で 4 割を越えて いる. 次に多いのが国道から一般道への変更で約 2
割, 同程度の一般道への変更は 1 割である. 一般道か ら高速道路への変更も約 1 割見られ，高速道路が代替 機能を果たしているといえる.

表.2 利用ルートの変更パターン

\begin{tabular}{lcc}
\hline 利用ルートの変更パターン & 人数 $($ 人) & 構成比 $(\%)$ \\
\hline (1)二桁国道から三桁国道への変更 & 24 & 43.6 \\
(2)国道から一般道への変更 & 13 & 23.6 \\
(3)県道から一般道への変更 & 2 & 3.6 \\
(4)高速自動車道から一般道への変更 & 2 & 3.6 \\
(5)県道から国道への変更 & 2 & 3.6 \\
(6)一般道から高速自動車道への変更 & 6 & 10.9 \\
(7)同程度の一般道への変更 & 6 & 10.9 \\
\hline \multicolumn{2}{c}{} & 55 \\
\hline
\end{tabular}

次に, 経路変更による危険度の変化に着目してこの 表をさらに集約したのが表.3である. 四国地域（とり わけ山間部) の道路整備状況を見ると, 主要幹線に比 べて非幹線道路の整備・管理水準は低い，高速道路や 直轄国道を除くと線形の悪い区間や狭幅員区間が多 く，豪雨などによる斜面崩壊に対する施設の整備も不 十分で, 通行のリスクも高いと考えられる. そこで, 本研究では, 便宜的に危険度の大小関係は道路の機能 に比例するものと仮定した. すなわち, 危険度の小さ い方から順に, 高速道路＜二栃国道＜三杵国道＜県道 <一般道である. なお，危険度の設定については，過 去の災害時の通行規制データからそれを判定するなど の方法も考えられる。しかしながら，直轄国道以外の 県あるいは市町村管理の道路について，過去の規制実 績のデー夕を体系的に入手することは困難であった. したがって, 上記のように道路機能と危険度を対応さ せるものとした.

経路変更により危険度が増大するとみなされるの は，表.3の(1)，(2)，(3)，(4)のケースであり,このパ ターンに該当するのは41名（74.5\%）である．危険度 が低下するのは(5)，(6の 2 ケースで該当するサンプル は8名（14.5\%），危険度の変化がないのは77で6名（ 10.9\%）である.このことから，迂回路を利用する場 合は 7 割以上のドライバーが危険度の高い経路へ変更 していることがわかる. 実際、国道の通行が遮断機に より事前に規制されるような場合でも、地方道は物理 的手段によって通行を遮断することが難しい。幹線道 路の規制により、ドライバーは逆にリスクが高い道路 の通行を余儀なくされるような状況も発生しているの 
である.

表.3 危険度の変化に着目した利用ルートの変更パ

\begin{tabular}{|c|c|c|}
\hline 危険度の変化パターン & 人数 (人) & 割合 (\%) \\
\hline 大きくなる (1), (2), (3), (4)) & 41 & 74.5 \\
\hline 小さくなる (5), (6) & 8 & 14.5 \\
\hline 変化なし (7)) & 6 & 10.9 \\
\hline 計 & 55 & 100 \\
\hline
\end{tabular}

\section{5. 仮想的状況下での選択行動(調查票IIの分析)}

トリップの中止・迂回・待機の選択は, 平常時と比 べたそれぞれの場合の所要時間の大小によるものと考 えられる. 調查票Iによって仮想的状況下での選択行 動のデータが得られているので, 平常時の所要時間 $\left(\mathrm{t}_{\mathrm{o}}\right)$ , 迁回経路の所要時間 $\left(\mathrm{t}_{\mathrm{d}}\right)$, 一旦待機して再びトリップ したときの所要時間 $\left(\mathrm{t}_{\mathrm{w}}\right)$ を組み合わせて説明変数を作成 し, 非集計ロジットモデルにより通行規制時の交通選 択行動を分析した.

\section{(1) モデル構造}

配分モデルに組み込むことのできる簡明な選択行動 モデルとするために, 説明変数を所要時間に限定して 分析を進めた. 3 つの時間変数 $\left(\mathbf{t}_{0}, \mathbf{t}_{\mathrm{d}}, \mathbf{t}_{\mathrm{w}}\right)$ の組み合わ せによるいくつかのロジット型段階的選択行動モデル を仮定した. すなわち，ドライバーは第 1 段階として トリップを中止するか（行動s）中止しないか（行

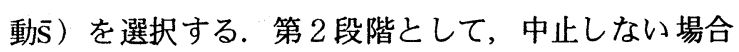
は, 迁回するか(行動d), 待機するか (行動w)を選択す るものとした. 第 2 段階の選択の説明変数には平常時 経路との時間比あるいは時間差を用いた. 第 1 段階の 選択には，下位の選択である第 2 段階の選択のlogsum 変数あるいは時間比（時間差）の小さい方を説明変数 とするモデルを考えた．以下，便宜的に第 2 段階，第 1 段階の順に選択モデルの推定結果を示す.

\section{(2)迂回・待機行動モデルの推定}

トリップを中止しない場合に过回する確率は次式で 与えられる.

$$
p(d \mid \bar{s})=1 /\left\{1+\exp \left(V_{w}-V_{d}\right)\right\}
$$

ここに， $\mathrm{V}_{\mathrm{d}}, \mathrm{V}_{\mathrm{w}}$ はそれぞれ迁回および待機する場合の 効用の確定項である．時間比モデルでは, 確定効用の 差は,

$$
V_{w}-V_{d}=\alpha_{0}+\alpha_{1}\left(t_{w} / t_{0}-t_{d} / t_{0}\right)
$$

であり, 時間差モデルでは,

$$
\mathrm{V}_{\mathrm{w}}-\mathrm{V}_{\mathrm{d}}=\alpha_{0}+\alpha_{1}\left(\mathrm{t}_{\mathrm{w}}-\mathrm{t}_{\mathrm{d}}\right)
$$

である. $\left(\alpha_{0}, \alpha_{1}\right.$ はパラメータ $)$

目的別にパラメー夕推定の結果を表. 4 に示す. 目的 によってトリップ中止の傾向が異なるので, 迁回・待 機モデルの推定に用いたサンプル数は, 通勤(320), 業 務(329), 観光(132), 私用(169)である. 時間比モデルで

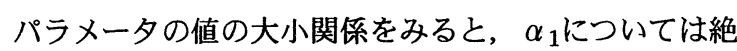
対值も値も業務>通勤>観光>私用の順に大きく，こ の順に待機よりも迁回の傾向が強いことがわかる．ま た，通勤や私用に比べて，業務や観光のパラメータ $\alpha_{0}$ は大きく, 時間比が同じなら待機の傾向が強いことを 意味している.

時間比モデルに比較すると, 時間差モデルの全体的 説明力はやや低下する. パラメータ $\alpha_{1}$ の值が示す傾向 は, 時間比モデルと同様である.

表.4 迁回待機行動のパラメータ [] 内はt值. 以下同

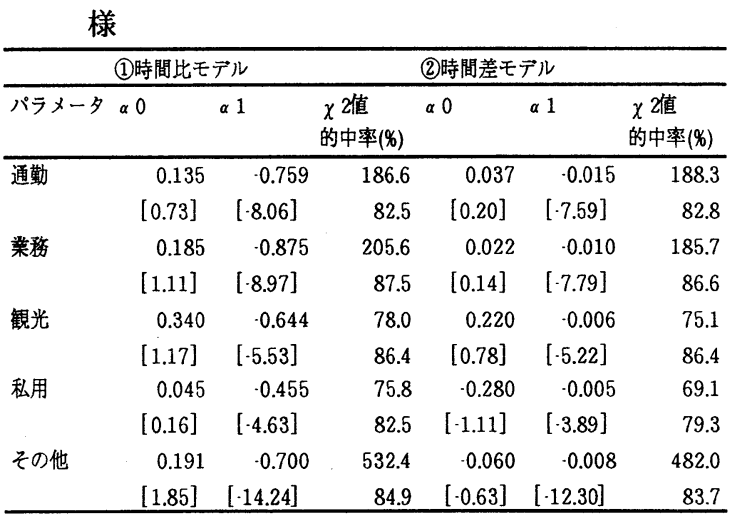

\section{(3)中止行動モデルの推定}

中止行動の選択確率は,

$$
\mathrm{p}(\mathrm{s})=1 /\left\{1+\exp \left(\mathrm{V}_{\overline{\mathrm{s}}}-\mathrm{V}_{\mathrm{s}}\right)\right\}
$$

である。ここに $\mathrm{V}_{\mathrm{s}}, \mathrm{V}_{\mathrm{s}}$ はそれぞれ中止した場合としな かった場合の効用の確定項である. 中止行動モデルと 
しては, (i)比較最小モデル, (ii)Nestedモデルの二つを 検討した.

(i)比較最小モデル

平常時の所要時間と比べたときの迁回あるいは待機 した場合の時間の比（あるいは時間の差）を求め, そ の小さい方をトリップする場合の効用関数に組み込ん だモデルを考える．これを便宜的に比較最小モデルと 呼ぶ. 効用差は，それぞれ

$$
\begin{aligned}
& V_{\bar{s}}-V_{s}=\beta_{0}+\beta_{1} \min .\left\{t_{d} / t_{0}, t_{w} / t_{0}\right\} \\
& V_{\bar{s}}-V_{s}=\beta_{0}+\beta_{1} \min .\left\{t_{d}-t_{0}, t_{w}-t_{0}\right\}
\end{aligned}
$$

で与えられる. $\left(\beta_{0}, \beta_{1}\right.$ はパラメータ $)$

パラメー夕推定の結果を表. 5 に示す. サンプル数は いずれの目的も513である. 時間差モデルに比べて時間 比モデルの説明力はやや低い. パラメータの絶対値の 大小関係を見ると， $\beta_{0}$ につては時間比, 時間差モデ

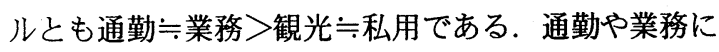
比べて，観光や私用ではトリップを中止する傾向が強 いことを示している. パラメータ $\beta_{1}$ につては, 目的 による傾向の差異を明確に読みとることが難しい.ま た, 迂回・待機モデルに比べると, $\beta_{1}$ の値は小さく

\begin{tabular}{|c|c|c|c|c|c|c|}
\hline & \multicolumn{3}{|c|}{ (1)時間比モデル } & \multicolumn{3}{|c|}{ (2)時間差モデル } \\
\hline パラメータ & $\beta 0$ & $\overline{\beta 1}$ & $\begin{array}{l}\chi \text { 值 } \\
\text { 的中率(\%) }\end{array}$ & $\beta 0$ & $\beta 1$ & $\begin{array}{l}\chi \chi \text { 值 } \\
\text { 的中率(\%) }\end{array}$ \\
\hline \multirow[t]{2}{*}{ 通勤 } & 2.998 & 0.585 & 103.3 & 3.016 & 0.015 & 176.6 \\
\hline & {$[8.83]$} & {$[\cdot 7.85]$} & 68.2 & {$[10.91]$} & {$[-9.86]$} & 76.0 \\
\hline \multirow[t]{2}{*}{ 業務 } & 2.026 & 0.366 & 65.6 & 2.576 & $\cdot 0.008$ & 159.7 \\
\hline & {$[6.28]$} & {$[-4$.} & 60.8 & [10.76] & {$[-9.13]$} & 74.3 \\
\hline \multirow[t]{2}{*}{ 観光 } & 1.870 & $\cdot 1.021$ & 200.0 & 1.181 & 0.011 & 222.9 \\
\hline & {$[5.04]$} & {$[-7.74]$} & 76.2 & {$[4.31]$} & {$[-7.76]$} & 77.4 \\
\hline \multirow[t]{2}{*}{ 私用 } & 1.454 & .0 .669 & 106.1 & 2.004 & .0 .020 & 191.9 \\
\hline & {$[4.26]$} & {$[\cdot 6.45]$} & 70.8 & {$[6.73]$} & {$[\cdot 8.74]$} & 72.5 \\
\hline \multirow[t]{2}{*}{ その他 } & 0.796 & $\cdot 0.263$ & 64.0 & 1.448 & -0.008 & 345.4 \\
\hline & {$[5.73]$} & {$[\cdot 7.14]$} & 60.7 & [13.38] & {$[-15.40]$} & 69.3 \\
\hline
\end{tabular}
はないものの, 中止モデルの説明力は相対的に低い.

(ii)Nestedモデル

第 2 段階の選択肢（迁回および待機）の魅力を表す logsum変数は,

$$
\Lambda=\ln \left\{\exp \left(\mathrm{V}_{\mathrm{d}}\right)+\exp \left(\mathrm{V}_{\mathrm{w}}\right)\right\}
$$

で表される.この変数が, 中止しない場合の勃用を説 明するものとした. 効用差は,

$$
\mathrm{V}_{\mathrm{s}}-\mathrm{V}_{\mathrm{s}}=\beta_{0}+\beta_{1} \Lambda
$$

となる. パラメー夕推定の結果を表. 6 に示す. モデル 全体の説明力は，比較最小モデルとほぼ差がないかや

\begin{tabular}{|c|c|c|c|c|c|c|}
\hline \multirow{2}{*}{ パラメータ } & \multicolumn{3}{|c|}{ (1)時間比モデル } & \multicolumn{3}{|c|}{ (2)時間差モデル } \\
\hline & $\overline{\beta 0}$ & 31 & $\begin{array}{l}\chi \text { 值 } \\
\text { 的中率 }(\%)\end{array}$ & $\overline{\beta 0}$ & $\beta 1$ & $\begin{array}{l}\chi \text { 2 2值 } \\
\text { 的中率(\%) }\end{array}$ \\
\hline \multirow[t]{2}{*}{ 通勤 } & 2.959 & 0.790 & 101.7 & 3.283 & 0.859 & 174.4 \\
\hline & {$[8.78]$} & [7.79] & 68.2 & [10.99] & [9.97] & 76.2 \\
\hline \multirow[t]{2}{*}{ 業務 } & 1.918 & 0.398 & 63.6 & 2.616 & 0.642 & 153.9 \\
\hline & {$[6.16]$} & [4.59] & 62.6 & [10.59] & {$[9.06]$} & 74.7 \\
\hline \multirow[t]{2}{*}{ 観光 } & 1.400 & 1.312 & 184.0 & 0.950 & 1.210 & 187.2 \\
\hline & {$[4.01]$} & [6.97] & 75.8 & {$[3.21]$} & {$[6.62]$} & 73.9 \\
\hline \multirow[t]{2}{*}{ 私用 } & 0.775 & 1.218 & 93.6 & 0.306 & 2.122 & 146.2 \\
\hline & {$[2.79]$} & {$[5.53]$} & 67.8 & {$[2.07]$} & {$[7.84]$} & 66.7 \\
\hline \multirow[t]{2}{*}{ その他 } & 0.738 & -0.366 & 60.0 & 1.400 & -0.783 & 336.9 \\
\hline & {$[5.43]$} & {$[-6.87]$} & 57.9 & [13.22] & {$[-15.42]$} & 69.0 \\
\hline
\end{tabular}
や低い．パラメータの絶対值の大小関係を目的別に比 較すると， $\beta_{0}$ は通勤・業務で大きく，観光・私用で小 さい. $\beta_{1}$ につては，明確な傾向を見いだせない.

非集計分析の結果は以下のようにまとめられる. (1) 迁回・待機モデルとしては, 時間差よりも時間比を用 いたモデルのほうがやや再現性に優れている. (2)中止 行動モデルは过回・待機モデルよりも説明力がやや低 下する. Nestedモデルと比較最小モデルの説明力の差 は小さい，また，時間比よりも時間差を用いたほうが 再現性が良好である。(3)迁回・待機モデルではパラ メー夕值と目的との関連性に明確な傾向を見いだせる が，中止モデルの場合には必ずしも同様の傾向が見ら れるとは限らない. 中止モデルについては, 構造の再 検討が必要かもしれない.

\section{6. 四国地域道路網への適用}

通行規制時の迁回・待機・中止行動についての分析 の結果得られた行動モデルをネットワークモデルに組 み込んで, 実際の道路ネットワーク上で交通量を求 め, 通行規制の影響を調べる. 以下では, 平常ルート の交通量や迁回ルートの交通量を求める際に，OD間の 時間最短経路へOD交通量のすべてを負荷する. 実際の 通行規制では, 迁回車両による新たな混雑の発生や, それに伴う代替経路の所要時間の増加も生じる可能性 があるが，それらは考虑されない.ネットワークへの 
配分は必ずしも現況再現を意図したものではなく， All-or-Nothingルールを適用したときのリンク交通量の 挙動を知るためのものである. 規制の有無による比較 は，需要交通量ベースの議論であることに留意された い.

\section{(1)前提条件}

対象ネットワークは，四国地域の幹線道路網で，国 道, 主要地方道に加え, 一部の一般地方道を含んでい る. 通行規制として, 近年最も規制が大規模であった 平成 5 年 9 月 3 日〜 4 日の台風 13 号による規制を取り 上げた．規制箇所は図.2に示す16ヶ所であり，幹線国 道の異常気象時通行規制区間のほとんど全てが通行規 制された。高松〜高知間の国道32号線や松山〜高知間 の国道33号線は非常に広範囲にわたって通行不能で あった.

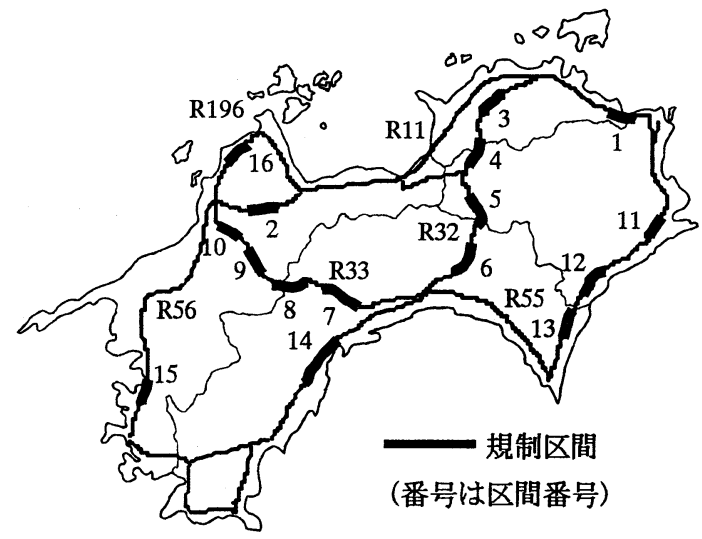

図.2 平成 5 年 9 月 3 日〜 4 日の台風13号による規 制箇所

規制時間の最小は6時間30分，最大は12時間であり，ほ とんどの区間は約8時間で規制が解除された．規制時間 の長さは, アンケートの調査票IIて想定した値の範囲 内にあるとみなされる．また，規制区間の空間的分布 を見ると，平常時に規制区間を通行するであろうと考
えられる交通の多くは都市間・地域間のトリップであ る. それらのトリップに要する平常時の所要時間は, 概ねアンケートで想定した值の範囲にあると考えられ る.

$\mathrm{OD}$ 表は平成 2 年度の建設省道路交通センサスによ るBゾーンOD表をトリップ目的別に集計したものを 用いた. トリップ目的は, 通勤, 業務, 観光, 私用, その他とした. 通行規制時のドライバーの迁回・待機 行動は，時間差を説明変数とするモデル，中止行動は 同じく時間差を説明変数とする比較最小モデルを用い るものとした. 过回・待機モデルは時間差を変数とし ても時間比を変数としても再現性に大きな差はない が，中止モデルは時間差を説明変数とするほうが再現 性に優れているからである.

平常時のODペア間の所要時間は, 自由走行時間に よる最短経路上の時間とした. 平常時の時間最短経路 上に通行規制区間を含まないODペアは, 迂回・待 機・中止モデルの計算対象から除く，通行規制区間を 迁回する場合のOD 間所要時間は，規制区間に相当す るリンクを取り除いて求めた時間最短経路上の時間で ある. 待機する場合の $O D$ 間所要時間は，平常時の所 要時間に規制時間を加えたものである，厳密に言え ば, 待機の場合の所要時間は, 個々のトリップの発生 時刻と規制の開始時刻により異なると考えられる. し かしながら，そのような個別で動的な処理を行うこと にすると, 数値計算操作がきわめて煩雑になるため, ここでは上記のように平均的な扱いとしている.

(2)中止行動之迁回・待機行動

表. 7 に交通目的別の中止トリップ数および过回・待 機トリップ数を示す．影響ODペアおよび影響トリップ 数とは，平常時に比較して通行規制時のOD間所要時間 の値が大きくなるようなODペアとそのトリップ数をい

表.7 交通月的別の中止・迁回・待機の状況

\begin{tabular}{|c|c|c|c|c|c|c|}
\hline 交通目的 & $\begin{array}{l}\text { A : 配分対象 } \\
\text { トリップ数 }\end{array}$ & $\begin{array}{l}\text { B : 影響トリッ } \\
\text { プ数(B/A,\%) }\end{array}$ & $\begin{array}{l}\mathrm{C}: \text { 影響OD } \\
ヘ ゚ ア \text { 数 }\end{array}$ & $\begin{array}{l}\mathrm{D} \text { : 中止トリッ } \\
\text { プ数(D/B,\%) }\end{array}$ & $\begin{array}{l}\mathrm{E}: \text { 迂回トリッ } \\
\text { プ数 }(\mathrm{E} / \mathrm{B}, \%)\end{array}$ & $\begin{array}{l}\mathrm{F} \text { :待機トリッ } \\
\text { プ数 }(\mathrm{F} / \mathrm{B}, \%)\end{array}$ \\
\hline 通勤 & 507,427 & $9,278(1.8)$ & 188 & $1,021(11.0)$ & $8,231(88.7)$ & $26(0.3)$ \\
\hline 業 & 815,295 & 334 & 638 & & 29,255 & $40(7.9)$ \\
\hline 観 & 11 & 4 & 133 & & 2,8 & $336(6.8)$ \\
\hline 私用 & 202,554 & $4,178(2.1)$ & 104 & 5.1) & $2,495(59.7)$ & $216(5.2)$ \\
\hline その他 & & $27,647(4.4)$ & 656 & $7,613(27.5)$ & $19,415(70.2)$ & $619(2.2)$ \\
\hline$E 1$ & $2,571,746$ & $79,471(3.1)$ & 0 & $15,383(19.4)$ & $62,253(78.3)$ & $1,837(2.3)$ \\
\hline
\end{tabular}


う. トリップ数の多い都市部のリンクが規制されるこ とはないので, 配分対象トリップ数に対する影響卜 リップ数の割合は3\%程度であり, 著しく多いとは言え ない. 交通目的別に見ると, トリップ長の長い観光や 業務目的のトリップが影響を受けやすいことがわか る.

中止・迂回・待機の割合を見ると, 迁回が 8 割, 中 止が 2 割であり，待機するケースはほとんど見られな い. 規制時間が概ね 8 時間程度であったため, 規制さ れていないルートが残されておれば过回してでもト リップするか，迁回ルートがない場合には中止する割 合が高くなったものと考えられる．通勤や業務では中 止率は 1 割程度であるが，観光や私用では 3 割を越え る. 実際の通行規制時の行動の分析（第 4 章，たとえ ば表. 1 ）によれば，中止率は全体で15\%，通勤・業務 では $8 \%$ ，観光・私用では40\%であったからここでの 結果はそれとも概敉合している.

表. 8 にトリップ中止率の高いODペアを目的別に上 位 3 位まで示す．この表を見ると，トリップが中止さ れやすいのは, 国道11，32，33，55，196号線を経路と するＯDペアであり，海岸部・山間部を経由している ものであることがわかる．これらの経路を利用する ODペアは，設定した規制条件下では特に有効な迁回 路をもたなかったとみなされる.

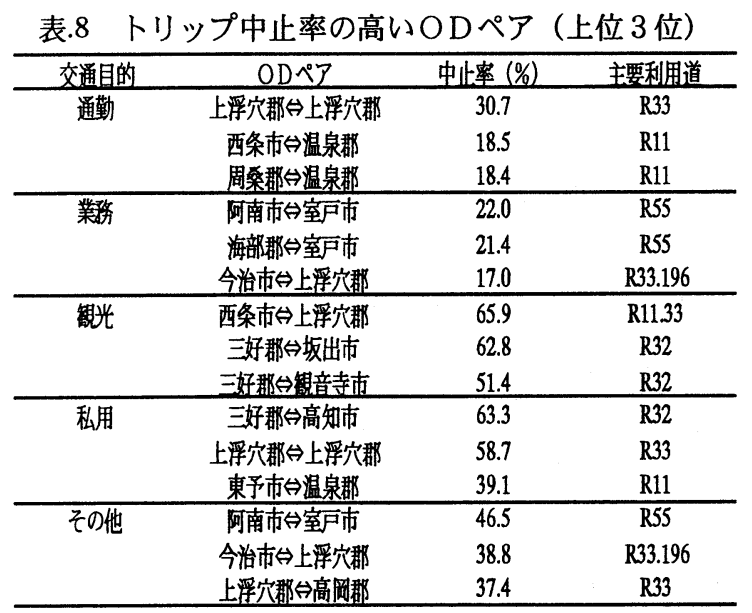

(3) 平常時と規制時のリンク交通量の比較

平常時のOD交通量を時間最短経路にAll-or-Nothing配
分して求めたリンク交通量と, 通行規制時に規制の影 響を全く受けないかまたは迁回したOD交通量を規制 ネットワークにAll-or-Nothing配分して求めたリンク交 通量を比較する. 規制区間のリンク走行時間は, 平常 時の值に規制継続時間を加えた值である. また，規制 時に配分されないトリップは, トリップを中止するか 待機したものである.なお，先に述べたように，この 配分はAll-or-Nothing配分ルールによるNetwork Loading のP erformanceを調べることが狙いで，必ずしもAll-orNothing配分が通行規制時のフロー記述手法として十分 であると考えているわけではない，过回交通による混 雑の発生などを考虑した配分へ展開するための予備的 検討段階にあるものである.

多数の規制区間を持つ国道33号線の愛媛・高知県境 付近（図. 3) を例に, 平常時のリンク交通量と規制時 のリンク交通量を比較する. 規制区間の平常時の日交 通量（計算値）は，約2,200台（リンク934）から約 5,000台（リンク698）である. 愛媛県側では, 久万町 〜研部町（リンク698）が規制されることにより，国道 379,380 号線（リンク706,707,710,709） へ迁回交通が流 れ，これらの区間ではリンク交通量が約2,000台増加す る. 規制区間に隣接する国道33号線のリンク702,705で は，平常時に比較してそれぞれ $1,800 ， 3,000$ 台の交通量 が減少する. 高知県側でも同様に, リンク934,935など が規制されることにより，国道194,439号線（リンク 931,932,933）の交通量が700〜 1,800台増加する.

図.4は，いくつかのリンクについて交通量の目的別 の内訳の変化を示したものである. 全体に通勤や業務 目的の交通の割合が高くなっている. とくに，規制区 間に挟まれた国道33号線上のリンク697,702では通勤交 通の割合が増え, リンク932では業務交通の割合が顕著 に増加していることがわかる. 通行規制時にも中止さ れにくい通勤や業務交通は, 平常時には利用されない ような経路へ迁回する可能性があることを示唆してい る.

\section{7. おわりに}

通行規制されたネットワークにおけるドライバーの 交通選択行動について実証的な分析を行った結果, 得 られた主な成果は次のように要約できる. 


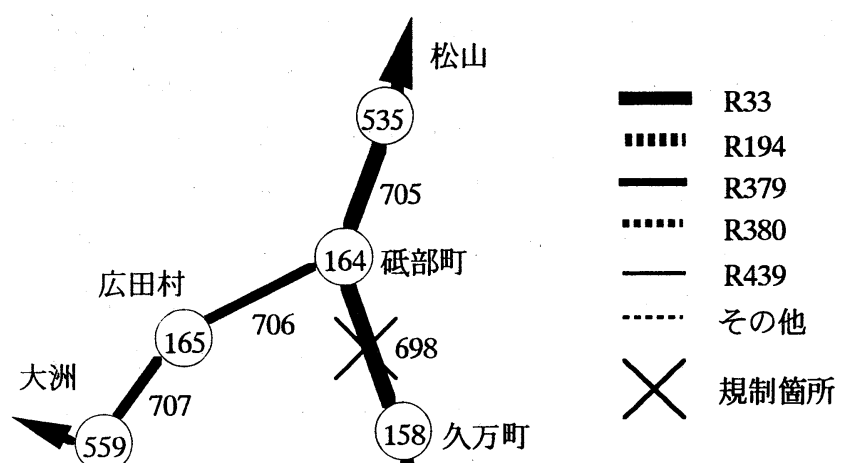

559) 697

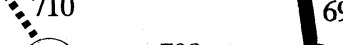

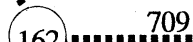<smiles>C1C[Sb]2CC1S2</smiles>

美川村

160 1053

池川町

小田町

702



161)

柳谷村
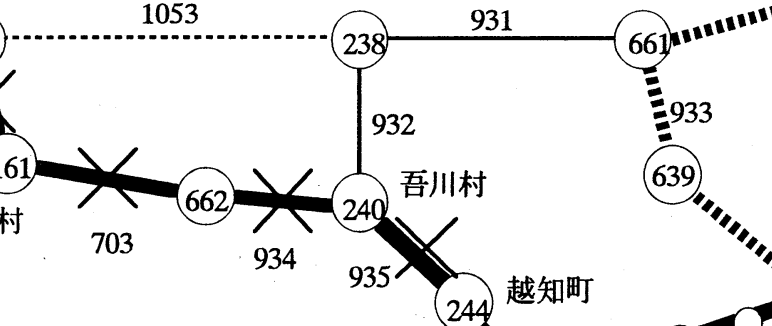

639)

703

図.3 国道 33 号線周辺のネットワーク

高知

to work business sightseeing daily private $\square$ others
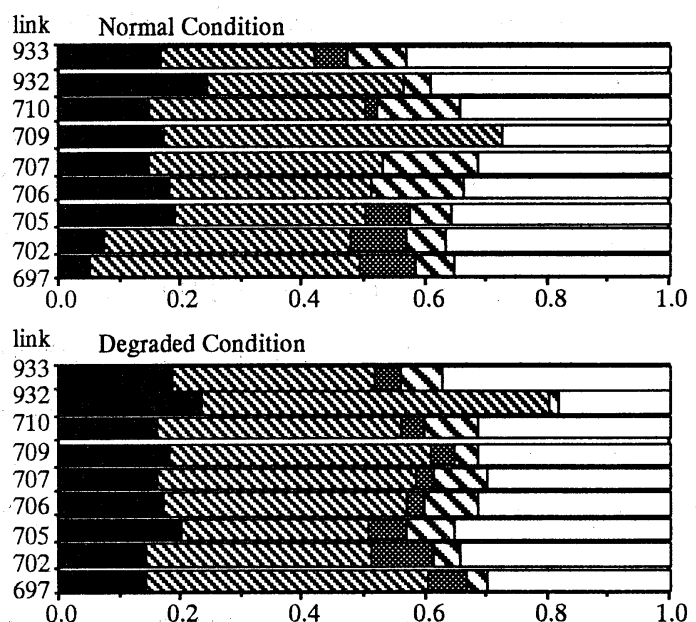

図.4 リンク交通量の交通目的構成の変化

（1）過去に災害による通行規制に遭遇した経験の有無 と, その際の交通選択行動を四国地域の建設省各工事 事務所等へのアンケート調査により調ベた。通行規制 に遭遇しても85\%のドライバーはトリップを中止する ことはなく，そのほとんどが迁回ルートを利用するこ とや，経路変更の際にはほぼ 7 割のドライバーがリス
クの高いルートへの変更を余儀なくされていることが わかった.

（2）仮想的な通行規制条件下での交通目的別の選択行動 を分析した結果，通行規制時の中止・过回・待機の行 動は，時間差や時間比によりある程度説明できること が確認できた. また, 時間差よりも時間比を用いたモ デルのほうがやや再現性に優れているが, 中止行動モ デルは迁回・待機モデルよりも説明力がやや低下する ことがわかった.

(3) 四国地域の道路ネットワークデータと交通センサス による交通目的別ODデータを用いて, 実際の通行規制 時における中止・过回・待機の行動モデルの適用計算 を行った. 規制の影響を直接受けるトリップ数は全体 の3\%程度であったが, トリップの中止率, 迁回率は(1) にまとめたドライバーの行動結果とよく一致すること がわかつた。

以上により，災害時の道路網信頼性評価モデルに組 み 込むことのできる交通量配分モデル開発のための基 礎的なデー夕が得られたと考えられる.もちろん今後 に残された課題も少なくない.とりわけ，(1)交通実態 調査のサンプル数を増やし，サンプルの偏りを是正す 
ること, (2)経路変更によるリスクの変化の検討につい ては，道路要因以外の要因も考慮した改良を加えるこ と, (3)交通量配分モデルへ適用するための簡明さを失 わない範囲で, 中止・迁回・待機 行動モデルの精緻化 を図ることが挙げられる.これらの諸点については, 検討を進めている段階であり，稿を改めて発表した い.

豪雨などを原因とする事前規制のように，年間に複 数回発生する可能性がある規制については, 規制時間 の長さなどについてドライバーはある程度の経験や知 識を持っていると考えられる. したがって，本論文で 述べてきたように，規制時間を説明要因の一つとして 交通量を推定するといった手順を取ることができよ う.しかしながら，極めて稀にしか発生しない通行規 制に対しては，このようなアプローチは必ずしも十分 ではないかもしれない.この点は, 期待値論的な信頼 性評価の考え方とも密接に関連しており, 今後の課題 としたい.

《参考文献>

（1）岡田憲夫, 若林拓史, 多々納裕一: 社会基盤整備の計 画・管理のためのリスク分析的アプローチ. 土木学会論文

集, No.464/IV-19,pp.33-42,1993.
（2）飯田恭敬, 若林拓史, 福田博: 道路網信頼性の近似解法 の比較研究. 土木学会論文集, No.311/IV-11,pp.107116,1989 .

(3) 高山純一：異常気像時における道路網の連結性能評価 法. 土木計画学研究・論文集, No.12,pp.559-565,1989.

（4）朝倉康夫, 柏谷増男, 熊本仲夫 : 交通量変動に起因する 広域道路網の信頼性評価. 土木計画学研究・論文集, No. 7,pp.235-242,1989.

(5) Du,Z-P.and Nicholson,A : Degradable Transportation Systems Performance, Sensitivity and Reliability An $の$ 比較研 究. 土木学会論文集, No.311/IV-11,pp.107-116,1989.

(6) Sanso,B.and Milot,L : A Reliability Model for Urban Transportation Planning.Preprints in TRISTAN-II Conference in Capri,pp.617-62,1994.

（7）朝倉康夫, 柏谷増男, 為広哲也 : 災害時における交通処 理能力の低下を考虑した道路網の信賴性評価モデル. 土木計 画学研究・論文集, No.12, pp.475-484,1995.

(8) 藤原健一郎, 朝倉康夫, 柏谷増男 : 交通ネットワークに おける災害時のフローの変化を考虑したODペア間の信頼度 の指標. 土木計画学研究・講演集18(2), pp.737-740,1995.

(9) Asakura, $Y$ and M.Kashiwadani : Traffic Assignment in a Road Network with Degraded Links by Natural Disasters, Journal of Eastern Asia Society for Transport Studies, Vol.1, No. 3,pp.1135-1152,1996.

\section{炎害による道路通行規制時の交通選択行動に関する実証分析}

朝倉康夫，柏谷増男，高木一浩，藤原健一郎

過去に災害による通行規制に遭遇した経験の有無とその際の交通選択行動および仮想的な通行規制条件下での交 通選択行動について，四国地域の一般ドライバーを対象にアンケート調查を実施した。通行規制に遭遇しても85\% のドライバーはトリップを中止することはなく，そのほとんどが迁回ルートを利用することや，経路変更の際に はほぼ 7 割のドライバーがリスクの高いルートへの変更を余儀なくされていることがわかった. 通行規制時の中 止・迁回・待機の行動は, 時間差や時間比によりある程度説明できることが確認できた. また, 中止行動モデル は迁回・待機モデルよりも説明力がやや低下することがわかった. 得られた行動モデルを四国地域の道路ネット ワークに適用し, 交通量配分モデル構築のための基礎的検討を行った. 規制の影響を直接受けるトリップ数は全 体の3\%程度であったが, トリップの中止率, 迁回率はドライバーの実際の行動とよく一致することがわかった. 
Empirical Studies on Travel Choice Behaviour in a Road Network Degraded by Natural Disasters

by Yasuo Asakura, Masuo Kashiwadani, Kazuhiro Takagi and Ken-Ichiro Fujiwara

This paper studies drivers' travel behaviour in a road network degraded due to natural disasters. Actual route choice and travel choice behaviour of drivers using a questionnaire survey are analyzed. It is found that $85 \%$ of drivers did not cancel their trips and use diversion routes. Due to the insufficient supply of road networks, $70 \%$ of diverted drivers were obliged to use lower class of road sections with higher risk of travel. Models describing travel choice behaviour are developed using disaggregate demand modelling methods. Those models are applied to the road network in the Shikoku area. Although $3 \%$ of drivers are effected by road section closure, the estimated trip cancel rate and diversion rate are consistent with actual travel behaviour in the degraded network. 